general feeling seems to prevail amongst the profession in London, that the aggregate meeting should be held in the metropolis at about the middle of JUnE. Meantime, individual members of the profession should petition the House of Commons, through their representatives, to stop the progress of the nefarious Bill. The form of a petition may be found in The Lances of April 26, page 473. Every petitioner can readily make the alteration which would adapt it to his particular case. The prayer of the petition should be for the postponement of the Bill until next session, or its total rejection.

\section{COUNTY MEETINGS OF MEDICAL PRACTITIONERS.} To the Editor of THE LANCET.

SrR, - Whatever may be the differences of opinion as to the merits or demerits of Sir James Graham's Bill for disintegrating the existing relations in the medical profession, it will unquestionably be attended by some important results for good or for evil. In order, therefore, that the profession may not have to reflect on its own supineness, nor be left in the lurch on the occasion, the only mode of effecting a representation of its opinions would be the calling of simultaneous county meetings in the different county towns, and the appointment of respective deputations from the several counties thus professionally assembled, to meet in London on or before the $7 \mathrm{th}$ of next month, to consult, and to arrive at what are the real interests of the profession, in relation to the Bill in question, and afterwards wait on their respective members of Parliament to urge the merits of the subject on their attention. I am, Sir, your obedient servant,

Shrewsbury, May 15, 1845. HEMRY Keate, M.R.C.S.L.

* * County meetings cannot be called too soon. A A really REPRESENTATIVE CONFERENCE in London would soon instruct Sir James Graham as to the feelings of the surgeons of England. The arrangements for the Aggregate Meeting will, it is hoped, be completed by next week. Meantime, the profession should petition the House individually, against the odious Bill.-Ev. L.

\section{ENFRANCHISEMENT IN THE COLLEGE OF SURGEONS. \\ To the Editor of THE LANCET.}

SIR,-Will you allow me to add my name to the list of those of my brother surgeons who are desirous of seeing the members of the College of Surgeons of England enfranchised in their parent College? I am, Sir, your obedient servant,

Radstock-cottage, Bath, May 19, 1845. Thomas Bounne, Surgeon.

\section{WITHDRAWAL FROM THE MISGOVERNED NATIONAL ASSOCIATION. To the Editor of THE LANCET.}

Srr, - I have written to Mr. ANcell, requesting the withdrawal of my name as a member of the miscalled "NATIONaI AssociTron," and I would recommend the adoption of the same course to all those who feel dissatisfaction with the conduct and intentions of the Committee. The Association is at present numerically strong, and of this strength the Committee take care to boast. Were the names of those members who are for union with the College of Surgeons to be struck off the list, and not for a new and beggarly incorporation, they wonld speedily find themselves weak, indeed, in numbers, as they doubtless are in the confidence of the members, and in the goodness of their cause.

I am, Sir, your obedient servant, Arteur Hril Hassali, M.R.C.S.L., F.I.S.

Norland-villa, Addison-road North, May 18, 1845 .

\section{ATTENDANCE OF ONE SURGEON FOR ANOTHER.} To the Editor of THE LANCET.

SIR,-The following occurrence, if published, may perhaps be edifying to some of your readers. I was engaged nearly the whole of last Saturday with a midwifery case, and in consequence of certain peculiarities which the case presented I could not leave until it had terminated; at the same time my attendance was required by another female, living rather more than half a mile from the place where I was. I gave the messenger my card, and the name of two or three gentlemen who resided very near the patient, with a request that some one of them would oblige me by attending; at the same time I desired her to delay as long as she could, in order that whoever attended might not have unnecessary trouble. She acted accordingly, and presented my card, herself, to two gentlemen, who both refused to attend, saying, "they knew nothing of me," and that " they should not go until they had a guinea." The poor woman not having a guinea with her was obliged to return home and procure one. On renewing her application, and showing one of them the guinea, there was no longer any hesitation; he instantly attended, was detained about half an hour, took the guinea, and has continued his attendance ever since.

Now. you may say what you please about the baser metals not possessing mesmeric properties; in this case there is positive proof of the efficacy of gold.

Southwark, May 14, 1845.

\section{FUTURE RESULTS OF THE PRESENT BILL.}

To the Editor of THE LANCET.

SrR, - The last appearance assumed by the chameleon Bill ought to be viewed by the profession as a mere change of external features, the obnoxious provisions of the previous editions all being retained. If the measure should become law, the foundation of division and confusion will be deeply laid. What with physicians, pure surgeons, pure licentiates in surgery, licentiates in medicine, licentiates in medicine and surgery, who are not " general practitioners," and licentiates in medicine and surgery who are "general practitioners," there will be such hustling and rivalry, such scuffing and hubbub, that the character of every grade will be lowered, and the confidence of the public lost.

Let any one cast his eyes into futurity, and imagine the course likely to be taken by men thus legally set against each other. Their studies and the difficulties of their duties would tend to bring them together and to promote offices of kindness and friendship; but by this Bill they would be broken up into numberless parties, each being provided with materials for jealousy and enmity, each seeking by any means to depress the rest.

The standing in society of the new licentiates in medicine and surgery will be infinitely below that now held by those who, having passed their examinations at the College and Hall, practise by the name of "surgeon." The public know their medical men by that name. The term "general practitioner" is entirely confined to the profession; and although it has been eagerly adopted by certain parties, it must be confessed to be an unmeaning and unprofessional appellation, yet having in it a whisper of something not very agreeable to patients. Your obedient servant,

W. N. I.

May 19,1845

\section{AGgREGATE MEETING OF THE PROFESSION AND \\ REPRESENTATIVE MEDICAL CONFERENCE.}

The arrangements for this Meeting and Conference are rapidly progressing. A committee-room will be opened at the Freemasons' Hall, Great Queen-street, Lincoln's-Inn Fields, on Monday next, where secretaries and clerks will afterwards be in attendance, daily, between the hours of twelve and five. Letters relating to the MeEting or Conference should be addressed,-

To the Honorary Secretaries,

Medical and Surgical Conference, Freemasons' Hall,

Great Queen Street,

London.

A very general opinion, we find, appears to prevail that the Aggregnte Meeting should be held, and the Conference commence its sittings, before Monday, June 16th. Probably some day in the week between Monday the 9 th and the 16 th would be the most appropriate period, and well suited to the objects of the profession, with reference not only to the mischievous and dangerous BILI, but also as regards the degrading APOTHECARX-CHARTER. At all events, the COUNTY MEETINGS should be held immediately; the RePresextatrves for the Con- 